\title{
A Re-READING OF JOHN 8:1-11 FROM A PASTORAL LibERATIVE PERSPECTIVE ON SOUTh African WOMEN
}

Author:

Elijah M. Baloyi ${ }^{1}$

\section{Affiliation:}

${ }^{1}$ Department of Practical

Theology, University of

South Africa, South Africa

\section{Correspondence to:}

Elijah Baloyi

email:

baloye@unisa.ac.za

\section{Postal address:}

PO Box 1061, Malamulele

0982, South Africa

\section{Keywords:}

pastoral counselling;

women abuse; gender

inequality; Africans; Jews

\section{Dates:}

Received: 22 Apr. 2010

Accepted: 06 Aug. 2010

Published: 30 Nov. 2010

How to cite this article:

Baloyi, E.M., 2010, 'A

re-reading of John

8:1-11 from a pastoral

liberative perspective on

South African women',

HTS Teologiese Studies/

Theological Studies 66(2),

Art. \#838, 7 pages. DOI:

10.4102/hts.v66i2.838

This article is available

at:

http://www.hts.org.za

\section{Note:}

This article was originally presented as a paper that was delivered at the

'Africa Conference' held on 26-28 March 2010 at the University of Texas in Austin, USA. (c) 2010. The Authors.

Licensee: OpenJournals Publishing. This work is licensed under the Creative Commons Attribution License.

\section{ABSTRACT}

The inception of democracy in South Africa faced the oppression of women as one of the challenges. The duty to improve women's position in society is not the responsibility of a few people alone, but of everyone. According to the researcher, the church has not done enough pastorally in this regard. In denouncing the oppression of women, the Christian community should also support the victims of abuse. This article intends to unmask collusion with patriarchal societies including the Jewish society in Jesus' time by mapping out the forms of harassment and embarrassment inflicted upon women. The study shows how pastoral care can help victims of oppression. A re-reading of John 8:1-11 will inform the, how can the verses above be used in counselling the victims of gender oppression. This study will formulate pastoral guidelines from Jesus' response to the Pharisees, the Scribes and the woman.

\section{INTRODUCTION}

The headline 'Woman killed for going on pill' (City Press 24 January 2010:8) is a real story wherein an uncaring husband decided to beat his wife (a mother of two) to death - openly and during the day after finding out that she was using contraceptives. This incident occurred in Thabazimbi, close to the border between South Africa and Botswana. To me this indicates that we still have women in society who are not allowed to think or assert their rights over their own bodies. I was deeply moved by this story, especially because there are many South African women who are suffering and even dying in silence under sophisticated male dominance. When reading from the Bible (specifically Jn 8, NIV), I tried to make a connection between the two stories (between Africans and Jews) and realised that I need to do something about this abuse, hence this article, written as one way to expose the attitude of some men towards women, an attitude that sees women as secondary human beings.

Our young democracy is celebrated year after year, yet some citizens of this country do not uphold its democratic values. I concur with Visser (2007:236) that South Africa is a traditional patriarchal society in which women and children have limited power and authority and are frequently exploited. Some people might be tempted to believe that the abuse of women is only an African problem, but this is incorrect as the story of the Jews in John 8 shows. This is one of the many examples that indicate how people in Judaism abused women and violated their rights. According to Groothuis (1994:32), women and slaves had no rights but were under the legal cover and control of their male masters. The issue of patriarchy, where men are normally the abusers and women accept the abuse without resistance, was also a problem in the Jewish community of New Testament times when Jesus was on earth, just as it is in South Africa today. In order to help South Africans with this problem of the abuse of women, we need to look at non-African cultures that have this problem too.

King (1989) explains that anger against oppressive structures of patriarchy has given birth to protest:

The protest is over the injustices of sexism subordinating one sex to the exploitative powers of another. It is a protest over the history-long exclusion of women from the centres of power and decision-making, their relegation to the spheres of nature and nurture, denying them full part in shaping the values of culture.

(King 1989:13)

In this way, cultural and traditional laws, rules and regulations were shaped by men alone, for the benefit of masculine seniority at the expense of women. This article is therefore aimed at uncovering, through the application of a relevant Biblical text, the issue of women abuse and harassment which is part of the Jewish patriarchal system. It is worrying that the Jewish community, from which Christianity originated, promoted the oppression of women. This might have been the reason why some cultures that received Christianity also accepted the culture of seeing women as secondary human beings.

This article will show how Jewish-structured rules, regulations and laws were carried over from Jewish times to Christianity and promoted the oppression of women. It is important to understand that the abuse that the women of those times suffered flowed from the way Jewish men subjected women to severe oppression. Jewish men dominated women not only in the home, but also on the religious scene where women had the same status as slaves. The rabbinical teachings of those days made it clear that women should be viewed as a temptation to sin and hence they had to be avoided at all costs. I shall be using the biblical passages to indicate how women were harassed and abused by men. These passages will give us a picture of how the Jews viewed women so that we can see some similarities between that society and our society which, today, is still fighting for women's rights. From the response of Jesus Christ, some pastoral guidelines will be drawn and advice given to assist an African pastoral caregiver to help women who are the victims of gender inequality.

\section{AFRICAN-SOUTH AFRICAN ABUSE OF WOMEN}

According to Baloyi (2009:103), there are many different ways in which women are abused in the African context. It is indisputable that African people, like many institutions in South Africa, are patriarchal, 
hence the fact that many women are victims of the system. The first form of abuse is found in African idioms which emphasise the domination of women in society. Some of the sayings or idioms are as follows:

'Lebitla la mosadi ke bohadi', meaning the grave of a woman is in her marriage or in-laws (Kriel 1991:27). This saying suggests that a woman should stay in her marriage even if the conditions there are life threatening, for instance, regular beating by the husband. In literal terms this idiom implies that a woman is not allowed to initiate divorce or separation but that such a right remains with the man. The unfortunate part of it is that the saying does not subject the man to similar conditions.

'Loko homu ya ntswele yi rhangela emahlweni, tita wela exidziveni,' literally means that 'if a female cow leads the herd, all cattle will fall into the pool.' This implies that when a woman takes the lead the life in the village deteriorates. It is for the same reason that families led by single mothers are underestimated, even though some raise their children with good values (Baloyi 2009:129).

The second form of abuse is wife beating: 'Where am I wrong when I beat my own wife?'; this was a response from a man who was summoned by elders in Driefontein near Piet Retief in Mpumalanga after beating his wife (City Press 18 February 2007:10). As wife beating and battering continues to be very common for some African men, many of them still do not believe that this is a crime according to the constitution of the country. Some of these men insist that they have a right to beat their wives because they paid lobolo or bride price for them. Dreyer (2009:5) tells two stories of women who were beaten, strangled and forced into sexual intercourse by their husbands who claimed that the wives should accept it as they had paid lobolo for them. According to Wasike and Waruta (2000:184), a Zimbabwean medical doctor (Dr Michale Mawena) sees nothing wrong with wife beating as a corrective measure - he claims that wife beating reduces divorces. In this way beating becomes structured and entrenched in cultural values. There are also those who beat their wives whilst they are drunk and the next day they either claim that they did not beat them or persistently plead for forgiveness (Baloyi 2009:148).

The third form of abuse entails women sometimes being forced to have sexual relationships unwillingly in their marriages, workplace and elsewhere. The Sunday Sun (24 July 2005:31) recorded an incident where a man took his wife and, with other men, gang-raped her in the bush in Bethal, Mpumalanga Province. The untold stories of women who were forced into sexual relations by employers remain as common in South Africa as that recorded by Marie Fortune in America (1989:29). The rapid growth of sexual offences has led the Commission on Gender Equality to write a report in which it asked the government to send its complaints to the Advertising Standards Authority (ASA) so that the advertising of women as sex objects could be minimised (City Press 13 November 2005:8). Masenya (2003) is perfectly correct in claiming that

[i]t may be argued that in a society where one's value as a human being is defined in terms of how one's body benefits those in power, the latter will also determine the treatment which such a body will receive.

(Masenya 2003:99)

In certain types of violations to women's bodies, there is a clear indication of the interconnectedness of individual and systematic violence. Therefore, if patriarchy as a system of domination is perpetuated by religion which naturalises male superiority and female inferiority, men will automatically find the violation of the female body natural too. These forms of abuse are closely related and connected to those of the Jews of Christ's time.

\section{A JEWISH VIEW OF WOMEN IN THE CONTEXT OF JOHN 8:1-11 AND OTHER SUPPORTING PASSAGES}

There are many theories that offer explanations for the occurrence of violence against women. Visser (2007:235) states that men abuse women because society allows them to and that some cultures even encourage this type of behaviour.

Rader (1983:41) indicates that the bulk of Jewish literature viewed a woman as a secondary creature who was created as man's helpmate - a view that served to justify and reinforce the separate and unequal roles of men and women in Jewish culture. The Jewish culture in the time of Jesus will serve as the context in which we will discuss John 8:1-11, which reads:

The teachers of the law and the Pharisees brought in a woman caught in adultery. They made her stand before the group and said to Jesus, Teacher, this woman was caught in the act of adultery. In the law Moses commanded us to stone such women. Now what do you say?

Thatcher (1993:69) indicates that the possible reason why the earliest manuscripts of the Bible excluded this episode might be Jesus' extraordinary refusal to sanction the sexual condemnation of this woman. It is unclear whether the accusers witnessed the act of adultery or whether they were just informed about it. The Bible does not mention how they separated the woman from the man so that they could drag her to Jesus. Without any reference to their own conduct as a sin in itself, the Pharisees and Scribes were not ashamed to interrupt people in their private lives. This indicates clearly how the Jewish law neglected human rights in the same way that we do in South Africa. In other words, the response of the accusers to this particular sin seems embarrassing; to them it was an act of executing the law.

The Pharisees and Scribes claimed that they found this woman having sexual intercourse with a man, as they say that she was caught committing adultery. But at the same time, no one bothers to ask about the man with whom she committed adultery. Meyers (2000:455) notes that 'Absent from the story is her partner who, if the woman is married, would also have been an adulterer.' For centuries, sexual attitudes, taboos and practices have been used by dominant groups in society to keep others subordinate (Spong 1988:23). The law that the Pharisees referred to is in Deuteronomy 22:22-25 which reads as follows:

If a man be found lying with a woman married to a husband, then they shall both of them die, both the man that lay with the woman, and the woman, so shalt thou put away evil from Israel. If a damsel that is a virgin be betrothed unto a husband, and a man find her in the city, and lie with her, then ye shall bring them both out unto the gate of the city, and ye shall stone them with stones that they die, the damsel, because she cried not, being in the city, and the man, because he hath humbled his neighbour's wife, so shall put away evil from among you. But if a man finds a betrothed damsel in the field, and the man force her, and lie with her, then the man only that lay with her shall die.

The other section that speaks of the same law is Leviticus 20:10, which reads: 'If a man commits adultery with another man's wife - with the wife of his neighbour - both the adulterer and the adulteress must be put to death.' (NIV) According to Meyers (2000:55), it is unclear whether the woman that was brought to Jesus had already been judged in the Jewish court or whether such a court would have had the right to carry out capital punishment in the 1st century. The interpretation of the actual law prescribed stoning only if she was a betrothed virgin and, according to Dockery (1998:476), the man also had to be stoned.

If adultery is always committed by two people of different sexes then the reason why the Jews brought only the woman to Jesus was a biased one. That is why I believe Leviticus 20:10 is correct when it says that both of the people should be put to 
death - not just one. Secondly, the same law did not mention any form of killing, but 'stoning' was the form they opted to use because they said it was what Moses had prescribed. This was an intended misreading and misinterpretation of the Bible by the Jews to further their own aims. This kind of Bible reading takes place when Bible readers want to use the Bible to execute their own agendas.

According to Lawrance (2007:21), adultery was an offence in Judaism that applied only to married women or to men who had sexual relations with a married woman. A married man who consorted with an unattached woman, a widow, a single woman or a prostitute was not considered an adulterer, but a polygamist (Lawrance 2007:22). Jewish culture viewed a woman as an inferior being. This incident shows vividly the cruel attitude the Scribes and Pharisees had toward women. They were not looking at this woman as a person at all, but as a thing or an instrument that they could use to formulate a charge against Jesus. Barclay (1975:5) argues that, to those Jews, the woman had no name, no personality and no feelings; she was simply a pawn in the game whereby they sought to destroy Jesus.

There are also a few contradictions regarding this law. Firstly, the law required the woman to be stoned if it was found that she was a betrothed virgin; however, such background information is lacking in this passage. To add to our understanding of 'betrothed', Spong (1988:117) indicates that it should be a relationship that is faithful, committed and public. The accusers seem to have ignored this part of the law for the sake of using this woman to devise a charge against Jesus. The other part of the law required both the man and the woman who were caught in adultery to be killed. However, in this scene nothing is said of the man. The Pharisees extended the law to mention 'stoning' as a method of execution in this case. They seemed to have purposefully left the man at large, as he did not feature in their evil plans. These people only wanted to use the law to suit and satisfy their own needs and not for the sake of justice. Men and male sexuality were regarded as active; females were regarded as more passive (Manning \& Zuckerman 2005:100).

Another important thing to note is that the Pharisees and Scribes did not take the man, too, to Jesus because they were also men and therefore had to protect other men at the expense of women. Men were regarded as holy whilst women were seen as corrupt secondary people. It is for this reason that Van der Walt (1988) says about Judaism:

The woman (wife) was literally locked up in the house. She had to be seen in public as little as possible, because she would with her innate cunning, seduce the innocent men. The Talmud warns us that men should not converse with women, even with their wives, too often because this would ultimately make them fall into immorality.

(Van der Walt 1988:21)

In other words, the woman was sexually restricted whilst the man was not. Sexual sins were understood to be the result of women seducing men. It was not common for the Jews to see men as perpetrators of rape or any sexual immorality because men were always viewed as being more pure and free from sexual sin than women and therefore men were the ones who were led into this sin by women. Perhaps this was the understanding that prevailed when the man was left on the run whilst the woman was forced to face Jesus. This is what Thatcher (1993:70) means when he says that the history of the interpretation of the text (Jn 8) shows an acceleration of bias against women.

According to Van Wyk (1985:38), the Jews believed that 'woman' was a blunder by God, as they looked for everything that could help them destroy the image of women. In Judaism men dominated the religious scene at the expense of women, to the extent that women were not allowed to read in the synagogue, whilst a male servant or a child was allowed to do this. In the context of 1 Corinthians 14:34-35 we can therefore understand Paul's exhortations (which barred women to teach or lead in the church, e.g. $1 \mathrm{Tm} 2: 11-12)$ to the women in the Jewish culture. Women were indeed generally excluded from the rabbinic hierarchies of achievement and the activities that related to religion like the study of Torah and the performance of mizvot. Women were generally held accountable only for those commandments that were negative, for example, 'Do not steal.' Women were not counted as members of a minyan (the quorum of ten men that is required for formal communal worship) nor were they to be called to read the Torah at worship services (Manning \& Zuckerman 2005:110).

To add to the hostility towards women, the Jewish culture did not allow women to be counted even when taking a census. This is why only the Gospel of Matthew (also a Jew) mentions that women were not counted in the feeding of the five thousand people. Matthew 14:21 records that '[t]he number of those who ate was about five thousand men, besides women and children.' Although some commentators reason that women were not allowed to walk the long distance to the mountain, the contentious issue is that those women who were present should have been counted if Jewish culture regarded men and women as equals. Another matter to take into consideration is that, according to Lawrance (2007:20), the Pharisees decreed that women should not be allowed to walk long distances, for example, from one city to another, unless they were accompanied by men who were their husbands.

According to the Jews, men were not allowed to speak to women in public because women could seduce the men and lead them into sin. Lawrance (2007:19) reports that 'In first century Palestinian Judaism, the Pharisaic interpretation apparently held that a proper woman never conversed with a man in a public place, that is, never with a man who was not her husband or kinsman.' This is why Jesus' disciples, having this law in their minds, were surprised when they found Jesus speaking to a Samaritan woman in John 4:27. The verse reads as follows:

Just then his disciples returned and were surprised to find him talking with a woman. But no one asked, 'What do you want or why are you talking with her?'

It is clear that their marvelling was motivated by the fact that, in Jewish law, no man was allowed to speak to a woman in public. Women were neither admitted as witnesses in court nor allowed either an active or a passive vote (Rader 1983:41).

According to the Jews, Jesus was contravening these laws. The Bible does not say whether the Pharisees who dragged the woman to Jesus in John 8 spoke to her or not. The act of 'dragging' her suggests stubbornness on their part and anger and violence towards her. This leads one to question whether she was found willingly performing this sexual act or whether she was raped or dragged into it without her consent. Thatcher (1993:70) indicates that, judging from the fact that there is no sign or mention of the male adulterer, the woman was presumed guilty even though she most certainly did not initiate the adultery. So, what about the man who was involved in this sinful act? It was fortunate for the Jews that Jesus did not ask them about the woman's partner because they would surely have found it difficult to answer. This is a sign that the Jews regarded a man as a ruler with unquestionable authority. They were not ashamed to leave him out when they brought the woman to Jesus.

The prayer is not only masculine, but also teaches men to view women as inferior people. This scene would have pleased Rabbi Yehuda (150 AD?) who taught that every Jewish man should in his daily prayer praise God and say: 'Praise is to you that you have not created me a heathen, a woman or a slave' (De Bruyn 1998:1). A slave or a heathen did not have any rights at all in a Jewish context. If one was a slave, it implied that one could be ordered around at will; this is also the level where the Jewish woman was seen to be. According to Bennet (1974:68), this prayer is echoed today when Orthodox Jewish men say 
in their morning prayer, 'Blessed art thou O Lord, King of the universe, who has not made me a woman.' These prayers were emphasised in rabbinical teachings and the main idea was that a woman was an inferior being who should be treated as lower than even a slave or a heathen. This is the background that led the Pharisees and Scribes to the unjust treatment of the woman who was brought to Jesus. It seems that the theology of the original sin was overlooked in Jewish thought; all the Pharisees wanted was to judge this woman, forgetting that they were sinners too.

\section{A BRIEF OVERVIEW OF THE POSSIBLE EFFECTS OF THIS TYPE OF ABUSE}

Masenya (2005:194) acknowledges the significant role that the Bible continues to play as a spiritual resource in the lives of many African women in South Africa. Thus, the reaction of women who read John 8 might be that the Bible is being used as a weapon of life-denying forces in the lives of African people. That is why Masenya (2005:195) advocates that the life-denying elements of the Bible, as well as those in African culture, need to be challenged and resisted. The fact that the Bible mentions nothing about the reaction of the woman leaves much to be desired but, in the light of the treatment she received from the Jewish leaders, one can at least speculate about how she must have felt when she was dragged to Jesus. The first thing that we note is that this woman was shamed and embarrassed before Jesus Christ. Even if we do not know how she regarded Jesus before this incident, we know she was forced to face a male religious figure just after she had been dragged from the scene where she was having sexual intercourse and it must have been the most devastating moment in her life. It is therefore not surprising that nothing has been recorded about her reaction. Such humiliation impressed some church fathers who regarded women as inferior people. Tertulian called a woman 'the devil's doorway' and Jerome attributed to women all the heresy (Maimela \& König 1998:127).

Dehumanisation is another concept that describes the situation in which this woman found herself. She was reduced to the status of a mere prostitute and this must have placed her under enormous emotional stress, because she could not avoid Jesus. This was a type of humiliation which no one would like to suffer. Leehan (1989:54) indicates the effects clearly when he says that sexual harassment is probably the most devastating form of abuse because of the intimate nature of the violation and the secrecy and privacy involved. He puts it this way: 'Sex is a private, intimate, even secret activity.' Even though we lack evidence from the woman herself, the fact that her own story was not heard opens the possibility that she might have been abused. This might explain the nature of the humiliation that Jewish woman had to suffer. Even if the woman was the initiator of the adulterous act (which was very rare in those times), the fact that some people rushed in and snatched her out of her privacy is a humiliation in itself.

The second reason why the woman did not go away from Jesus when the Pharisees and Scribes had left the scene is probably because she needed someone to help her out of her predicament. This is what most vulnerable women like her would do in such a situation. Even though much of her background is unknown (according to this passage), she was being portrayed as a prostitute. Even people who are actually prostitutes do not enjoy being treated like this: many of them would try to avoid being labelled prostitutes by explaining that they do not in fact want to do it but are forced by circumstances.

The Pharisees and Scribes expected Jesus to give a judgement against women. They brought a defenceless woman (perhaps half naked) to Jesus without also bringing her partner to be accountable for the misdeed. For every case to be fair, we have to hear the stories of all the people who are involved. For example, did the man rape her? Should she suffer for a second time after the rape? The truth remained untold because the one partner was absent. In this way the violation of female bodies become normalised in the male-oriented context (Masenya 2003:101).

\section{HOW TO USE JESUS' RESPONSE TO GIVE PASTORAL ASSISTANCE TO THE FEMALE VICTIMS OF ABUSE}

\section{He listened to the allegations}

Bons-Storm (1996:49) offers an opinion that whatever a woman says will be heard and regarded as the perspective of a woman, whilst what a man says and experiences is regarded as a perspective on being human. However, this was not the case with Jesus when He listened to the story about the woman who was brought to Him. If the woman had been given time to narrate her own story to Jesus, it would surely have been pathetic to listen to. But Jesus waited to hear the Pharisees' story very clearly before He responded to them.

According to Barnes and Barnes (1994:121), good understanding requires attentive listening. This is precisely what Jesus Christ did when the group of Pharisees and Scribes came to him. The important part was to respond adequately. Listening has always been one of the most precious gifts a pastor can have in order to succeed in helping people. Good judgment comes after good listening. For Jesus, the art of listening with love always led him to give good judgements. The fact that 'Jesus bent down and started writing on the ground' (v. 6b), indicates that he gave his undivided attention to the storytellers before responding to them. The truth is that, to listen with agape (love) requires one to counsel with a non-judgemental attitude, a readiness to help, tolerance, acceptance and unconditional positive regard (Boyd 1996:28).

We should also note that this was not the first time that Jesus listened and reacted to gender-related issues. In Mark 1:30 he listened when they reported to him the illness of Simon Peter's mother-in-law before he healed her. For a pastor, there is much power in listening. Listening is sometimes interrupted when the listener knows more than the person who is telling the story. Fischer (1988) says:

One of the principal ways in which spiritual companions assist the healing process is by being present to the person in her pain listening to her story, and offering her unqualified love and acceptance.

(Fischer 1988:160)

Another two scholars (Rappaport \& Seidman 2000:12) emphasise the importance of listening to narratives: 'Very often there are many other personal and communal stories that are hidden or silenced, especially those of minority groups. Their stories should be uncovered and heard.' Jesus was ready to listen to the stories as they were told which is why his dealings with narratives were exceptional. This love of listening (as Jesus demonstrated in the passage under discussion) reaffirmed the woman's worth and value and helped her to regain a sense of her own identity and power (Fischer 1988:160).

\section{He transformed a legal quibble into a human issue}

'If anyone of you is without sin, let him be the first to throw a stone at her' (v. 7):

The Pharisees and Scribes expected that Jesus would either condemn or liberate the woman but his statement does neither of the two. Condemnation and liberation were both understood as legal codes where the judge would decide either one of the two. Now, for Jesus to have told them to look at their own sins would have turned it into a moral issue that was redirected to them all, instead of the woman alone. 
The accusers withdrew only after Jesus answered them. This is what Cone (1986:43) meant when he claimed that God is the voice of the voiceless. Instead of violating the law as they expected, or allowing them to commit the injustice of stoning the woman, he left the matter to their own consciences (Carson et al. 1994:1042). This reflects one of the situations where some pastoral caregivers and pastoral counsellors find themselves without a way out. We have to learn that, whereas sometimes we cannot deal with problems legally, we are given the mandate to execute them morally.

The constitution of our country is clear about the fact that human rights (including the rights of prostitutes) should be protected at all costs. The question remains whether the legalisation of prostitution would benefit the moral life of our country, which is a concern for many. Not everything that is politically permissible will also be morally permissible or beneficial. This was not how Jesus handled the Pharisees. He did, however, allow them to be part of the solution by throwing a challenge back at them. He wanted them to rethink the matter and come forward with new ideas about the situation.

And this is exactly what is sometimes expected of a pastoral counsellor. You do not become an expert on a person's life; you help the person to help himself or herself. Swart (2003:28) says that, in counselling, counsellors have to make sure that they tell the client: 'We are in this together.' Jesus did not want to be the only judge; instead, he invited them to be part of the judgement. The fact that we do not condone sexual sins does not mean that we have to be judgemental of the victims; we have to protect them whilst we help them. This is the duty of a pastoral caregiver. On morality, Kretzschmar and Hulley (1998) contend that:

Morality is necessary because life without orientation is chaotic and meaningless. But morality is necessary not only for the preservation of life, but also for the quality of life. The Bible is seen as a source of guidance on moral issues.

(Kretzschmar \& Hulley 1998:14)

A pastoral caregiver should understand that, just as in the case of Jesus, some situations need not only legal systems to get the life of the victims back on track but also moral answers. In this manner, caregivers will spare themselves the task of being a judge instead of a pastoral helper.

\section{Jesus calls both men and women into responsibility and accountability}

'Go and leave your life of $\sin ^{\prime}$ (v. 1-11):

The first part of this statement, 'Go,' is a relieving statement which might have given the woman more time to believe. If this was not the first time that the Jews had punished women for the same offence, then this woman's first thought might have been that it was a mockery for Jesus to send her away. His action was contrary to Jewish expectation; this is what a pastoral caregiver should know and teach people about Jesus. God's will does not always follow the course we expect it to.

Jesus not only protected and helped the woman to escape from the hostility of the Jews - he also liberated her. It is very difficult, if not impossible, to liberate a person whom you do not protect. Women under violent attacks from men need such protection in order to bring hope and expectations of change. The statement 'He that is without sin among you, let him first cast a stone at

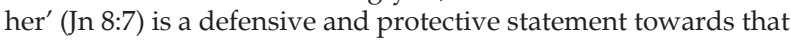
woman. It was known even to those Jews that all human beings have sinned; therefore it would have been difficult to stone her. Jesus made sure, firstly, that the woman felt safe so that he could speak to her. The protection offered by Jesus was also expected from the Jewish men who brought the woman to Jesus, as they were leaders and protectors of the households but, instead, they betrayed her (Masenya 2003:100). This was the true liberation that she needed in her life: he not only protected her physically, but also gave her the liberating message, 'Do not sin again,' which is a sign of Jesus' concern for the life of the woman. He used the external problem to deal with the internal problem of sin. Cone (1975:63) is well known for arguing that 'God takes the side of the oppressed.' His theology was that, in identifying oneself with the oppressed, one has to view the exodus not only as a historic event but also as a liberating event. He also says, 'Afflict the oppressor and support the oppressed' (Cone 1986:122).

This theology unpacks the whole idea of oppression and indicates that the Gospel is incomplete if it does not speak to the situation of the people. According to Cone (1986),

The resurrection event means that God's liberating work is not only for the house of Israel, but for all who are enslaved by principles and powers. In order to ease the pain of injustice on earth, the message of resurrection conveys hope and promises.

(Cone 1986:3)

Jesus took action. This is why liberation theology is also a theology of action and it requires solidarity between the oppressor and the oppressed. When all her accusers were gone, Jesus was left with the woman, to liberate her (Baloyi 2009:30).

Other instances in which Jesus is seen as a liberator include the story of the Samaritan woman in John 4 and the story of the bleeding woman in Luke 8:46. He broke the traditional and cultural barriers of gender by having women in his ministry (Lk 8:1-3), which was unlawful according to Jewish law. Pastors have to place themselves in the shoes of the oppressed in the community (like women) to help them out. This means that, if a pastor becomes judgemental with regard to, say, gender-related issues, he or she will not be in a position to liberate women. The pain and suffering of women who have been beaten by their husbands, abused and sexually harassed, requires caregivers to understand their plight. The stories of women in the New Testament portray the liberating power of Jesus' presence and message (Fischer 1988:83).

\section{The confrontational approach}

'Then neither do I condemn you', Jesus declared. 'Go now and leave your life of $\sin ^{\prime}$ (v. 11):

McMinn (2008:120) uses the concept 'gentle correction' in confronting sinners with their sins. Although there are many passages that support the idea of confronting pastoral clients with their own sins, the question remains: 'How does one do this?' Sometimes it is good to remember the wisdom of the following Old Testament proverb, 'A gentle answer deflects anger, but harsh words make tempers flare' (Pr 15:1-2). Jesus' words, 'Do not sin again,' were used at the appropriate time. Firstly, he said these words when only the two of them were left, as a sign that he never intended to humiliate her in front of other people. Secondly, the manner in which he said it was polite and humble so that the woman could see the love of Jesus in his words. Thatcher (1993:82) emphasises the point that the truth of God makes us aware of the crookedness of our own hearts and the fallen state of all creation. It is on this basis that the church should not shy away from confronting people with their own sins.

It is true that the woman was caught in adultery, which is a sin from the Biblical point of view, but it takes someone with wisdom, like Jesus, to address a woman who has just been accused of committing a sin. Truth is truth but pastoral caregivers should use the same truth in a loving way to reduce anger and fear in the victims of abuse. In this context, the fundamentalist or confrontational approach (also known as 'nouthetic') that Adams advocated is of relevance. It is in terms of this approach that Louw (1998:28) says that Adams attempts to guide the person to personal and behavioural change through a process 
of confrontation. Adams was, of course, trying to emphasise the importance of this approach because, in counselling, he preferred God's revelation to the psychological approach, which he disliked for his faith reasons. However, this is not the focus of this article.

\section{The gospel of forgiveness and a second chance}

'And leave your life of $\sin ^{\prime}$ (v. 11):

This statement suggests and promises forgiveness. It also has a promise of new life thereafter. The Christian view of grace, which assumes that humans are fallen and morally culpable before God, also means that everyone deserves a second chance. The statement, 'Go, and sin no more,' places the intention of forgiveness as a priority in the whole scene. Pastors often fail to reach people who are groaning in their sins because they do not have the message of forgiveness. According to Lee (1968:130) a client needs forgiveness by himself and of himself and of others towards whom he consciously feels animosity. It is very difficult for a pastoral caregiver to instil hope in someone who has been afflicted and abused, like the woman who was brought to Jesus, without assuring her of God's forgiveness. This is why it is necessary to underscore the fact that the instruction, 'Do not sin again' implies that she was forgiven.

Thatcher (1993:10) is of the opinion that the church is a community that exists to proclaim the necessity of repentance, forgiveness and reconciliation in personal and social human relationships and to announce the good news that God has provided the means of achieving this through Jesus. Thatcher (1993) maintains that

$[w]$ e need forgiveness and unconditional love to cure our crooked souls, and not just a compassionate companion through the unpredictable journey of life. Those committed to following Christ strive to become messengers of his grace, whether in counselling office or somewhere else.

(Thatcher 1993:82)

If the good news fails to make individual sinners aware that their sins are forgiven, such a gospel is incomplete.

Throughout Biblical history, God has revealed himself as a god who gives sinners a second chance in life and this is exactly how pastoral counselling can achieve its objective, even in terms of the downtrodden women in our society. Penner (1989:14) argues that Jesus did not reject the women who were known to be sinners (as the Pharisees would have expected); he enabled them to experience forgiveness. Wilson (1986:33) indicates that without it being pointed out that God has not finished dealing with our sin until he restores us to a complete place of blessing, the victim of abuse might never feel encouraged. This means that, at the end of the discourse, the message of forgiveness and a second chance will encourage and bring hope to the hopeless. The basic message of the Gospel is aimed at instilling hope in the hopeless.

\section{The church should transform beliefs and views about women}

The church should first and foremost - and by all means - make it a priority to regain the lost dignity of women. One undeniable fact is that the Bible teaches that every human being (women included) is created in the image of God. It is the main pastoral responsibility of the church to ensure that women are brought to the realisation that they are created to reflect God's image just as men are (Phiri 2003:26). This teaching should remain a priority when trying to assist women who, because of gender inequality, are silently used and abused by men. There are researchers who indicate that many women stoically remain silent even when their rights are being violated and they are being dominated by men, whilst the church becomes a spectator of such events Maluleke and Nadar (2002:14-15) have listed some causes of this silence: economic dependence, socially and culturally structured practices like lobolo and structural societal norms which train boys from a young age to be strong and aggressive leaders, whilst girls are expected to be obedient followers.

Phiri (2002:27) also indicates that the strong women's groups in churches, which help in similar situations in Africa, can also become centres of transformation for women. Church women from various denominations can be helped to organise themselves with a view to dealing with and minimising the abuse in their communities. In this context Kretzshmar (1995) comments:

Women, thus, need to develop a personal (interpersonal) consciousness. Self-esteem and self-confidence, based on a deep consciousness of being created by God, nurtured by their ongoing relationship with God, their true self and in relationship with others, will put women in a position to develop the insight and skills to affect the transformation of their context.

(Kretzshmar 1995:98)

I am in agreement with Maluleke and Nadar (2002:16) that transforming women's silence needs to convert and intensify their thoughts of resistance, as well as their weak, often counterproductive and incoherent survival strategies, into a growing self-confidence as, little by little; they gain more and more ground. It is gravely true that the suggested biblical hermeneutics should acknowledge the woman as a human person in her own right, not as an attachment to a male partner.

\section{CONCLUSION}

The oppression of women from a Jewish perspective has become an eye-opener to those who wish to understand and recognise women-abuse in South Africa. It is a travesty of women's rights that the Bible has been misinterpreted and abused to embellish, formalise and legalise societal values and norms which subject women to abuse by men. In this way the superiority of men against the inferiority of women has been naturalised and normalised from religion to culture. It is interesting to see how Jesus Christ reacted to the system of his day and helped even those who thought they were better than others, by showing them the moral rather than the legal truth. In this way, pastoral caregivers can use a non-judgemental approach to liberating the victims of legalised oppression. The very same misunderstandings and misinterpretations of the Bible should be taken into account when dealing with such cases. In the end, the pastoral caregiver has to show God's sovereignty in redeeming sinners.

\section{REFERENCES}

Baloyi, M.E., 2009, Patriarchal structures, a hindrance to women's rights, VDM Publishing Company, Saarbrucken.

Barnes, R. \& Barnes, R., 1994, We need to talk. Opening doors of communication with your mate, Zondervan Publishing House, Grand Rapids, MI.

Barclay, W., 1975, The daily study Bible. The Gospel of John, vol. 2, Saint Andrew Press, Edinburgh.

Bennet, R., 1974, I'm glad you asked that, Logos Publications, n.p.

Bons-Storm, R., 1996, The incredible woman, Abingdon Press, Nashville.

Boyd, G.E., 1996, The ART of agape listening: The miracle of mutuality, Agape House Press, Sugar Land, TX.

Carson, D.A, France, R.T, Motyer, J.A. \& Wenham, G.J., 1994 New Bible commentary 21st century edition, Intervarsity Press, Leicester.

'CGE Blasts misuse of women in ads', City Press, 13 November, 2005, p. 8

Cone, J.H., 1975, God of the oppressed, Seabury Press, New York.

Cone, J.H., 1986 Speaking the truth, Eerdmans, Grand Rapids, MI. 
De Bruyn, P.J., 1998, Feminist theology, Institute for Reformational Studies, Potchefstroom.

Dockery, D.S. (ed.), 1998, Concise Bible Commentary, Holman Reference, Nashville.

Dreyer, J.S., 2009, 'Holistic pastoral ministry and the challenge of violence against women', paper delivered at the Joint Conference of Academic Societies in the fields of Religion and Theology, Stellenbosch University, Stellenbosch 22-26 June.

Fischer, K., 1988, Women at the well: Feminist perspectives on spiritual direction, Paulist Press, New York.

Fortune, M., 1989, Is nothing sacred? When sex invades the pastoral relationship, San Francisco, Harper and Row.

'Gang raped woman in Bethal', The Sunday Sun, 24 July, 2005, p. 31.

Groothuis, R.M., Women caught in the conflict: The cultural war between traditionalism and feminism, Baker, Grand Rapids, MI.

King, U., 1989, Women and spirituality: Voices of protest and promise, Macmillan, Hampshire.

Kretzschmar, L., 1995, 'Women and culture: Ecclesial and cultural transformation', in C. Villa-Vicencio \& C. Niehaus (eds.), Many cultures, one nation. A festchrift for Beyers Naude, pp. 90-104, Human and Rousseau, Cape Town.

Kretzschmar, L. \& Hulley, L. (eds.), 1998, Questions about life and morality: Christian ethics in South Africa today, Van Schaik, Pretoria.

Lawrance, R.J., 2007, Sexual liberation: The scandal of Christendom, Praeger, London.

Lee, R.S., 1968, Principles of pastoral counselling, William Clowes, Britain.

Leehan, J., 1989, Pastoral care for survivors of family abuse, Westminster, Louisville.

Louw, D.J., 1998, A pastoral hermeneutics of care and encounter: A theological design for a basic theory, anthropology, method and therapy, Lux Verbi, Cape Town.

Maimela, S. \& König, A., 1998, Initiation into theology: The rich variety of theology and hermeneutics, Van Schaik, Pretoria.

Maluleke, T.S. \& Nadar, S., 2002, 'Breaking the covenant of violence against women', Journal of Theology for Southern Africa 144(Nov.) 5-17.

Manala, M.J., 2005, 'An Afro-Christian ministry to people living with HIV/AIDS in South Africa', HTS Teologiese Studies/ Theological Studies 61(3), 897-914.
Manning, C. \& Zuckerman, P., 2005, Sex religion, Thomson Wadsworth, Canada.

Masenya, M., 2003, 'Sacrificing female bodies at the altar of male privilege: A bosadi (womanhood) reading of Judges 19', Journal of Theology and Religion in Africa 27(1), 98-122.

Masenya, M., 2005, 'The Bible, HIV/AIDS and African-South African women: A bosadi (womanhood) perspective', Studia Historiae Ecclesiasticae June 1(1), 187-201.

McMinn, M.R., 2008, Sin and grace in Christian counselling, Intervarsity Press, Downers Grove, IL.

Meyers, C., 2000, (gen. ed.) Women in the Scripture, Eerdmans, Grand Rapids, MI.

Penner, C. (ed.), 1989, Women and men: Gender in the church, Mennonite Publishing House, Scottdale.

Phiri, I.A., 2002, 'Why does God allow our husbands to hurt us? Overcoming violence against women', Journal of Theology for Southern Africa 114(Nov.), 19-30.

Rader, R., 1983, Breaking boundaries: Male/female friendship in early Christian communities, Paulist Press, Toronto.

Rappaport, J. \& Seidman, E., (eds.), 2000, Handbook of community psychology, Kluwer Academic/Plenum Publishers, New York.

Spong, J.S., 1988, Living in sin, Harper and Row Publishers, San Francisco.

Swart, C., 2003, 'Caring with women married to Dutch Reformed clergymen: Narratives of pain, survival and hope', M.A. Research dissertation, University of South.

Thatcher, A., 1993, Liberating sex: A Christian sexual theology, Biddles Ltd, Guildford and Kings.

Van der Walt, B.J., 1988, The precious gift of love: Wetenskaplike bydraes van die PU vir CHO, Series F1 (366), Institute for Reformational Studies, Potchefstroom.

Van Wyk, J.H., 1985, 'Feministiese teologie [Feminist Theology]', In die Skriflig 19(75), 33-44.

Visser, M. (ed.), 2007, Contextualising community psychology in South Africa, Van Schaik, Pretoria.

Wasike, A.N. \& Waruta D.W., (eds.), 2000, Mission in African Christianity: Critical essays in missiology, Acton Press, Nairobi.

Wilson, E.D., 1986, A silence to be broken. Hope for those caught in the web of incest, Multnomah Press, Portland.

'Where am I wrong when I beat my wife', City Press, 18 February, 2007, p. 11

'Woman killed for going on pill', City Press, 24 January, 2010, p. 8. 